\title{
Hemodynamic complications during microlaryngeal surgery
}

\author{
Marinov Ts. ', M. Belitova', T. Popov², N. Nizamova², J. Rangachev², D. Popova ${ }^{2}$ \\ 'Department of Anesthesiology and Intensive Care; \\ University Hospital "Queen Giovanna"- ISUL; Medical University - Sofia \\ 2Department of ENT Surgery; University Hospital "Queen Giovanna"- ISUL; \\ Medical University - Sofia
}

\begin{abstract}
:
Introduction: Successful anesthetic management of microlaryngeal cases requires a high degree of cooperation with the surgeon, a reciprocal understanding of the potential problems, and adequate preparation on both sides to meet the anticipated challenges that may arise. The Aim of the study is to determine the hemodynamic complications during microlaryngeal surgery. Materials and Methods: A 5-year prospective cohort study of 200 patients who underwent microlaryngeal surgery in the Department of ENT Surgery; University Hospital "Queen Giovanna"- ISUL; Medical UniversitySofia. All patients were monitored and recorded for: Systolic blood pressure (SBP), Diastolic blood pressure (DBP); heart rate (HR); continuous electrocardiography (ECG). The above parameters were recorded and analyzed at predetermined time intervals: 5 -th minute before intubation, every 5 minutes after intubation and 5-th minute after extubation. Results and discussion: Mean systolic blood pressure of the patients during the operation is $147.33 \mathrm{mmHg}$, mean diastolic blood pressure is $93.5 \mathrm{mmHg}$ and mean pulse rate is 57.64 beats per minute. $49 \%$ of the patients have arterial hypertension I grade during the operation, $28 \%$ of them are with isolated arterial hypertension and $23 \%$ are with normal blood pressure. $40 \%$ of the patients had pulse rate between $45-60$ beats per minute during putting on the tube of Kleinsasser, $29 \%$ of them had pulse rate $>60$ beats per minute during putting on the tube of Kleinsasser and $31 \%$ had pulse rate $<45$ beats per minute during putting on the tube of Kleinsasser. Conclusion: Microlaryngeal surgery is specific kind of surgery which is characterized by hypertensive hemodynamic. There is a risk of severe bradycardia after putting on the tube of Kleinsasser which can cause hemodynamic instability and even cardiac arrest if not corrected immediately.
\end{abstract}

Key words: microlaryngeal surgery, hemodynamic complications, hypertensive hemodynamic, bradycardia

\section{Introduction}

Successful anesthetic management of microlaryngeal cases requires a high degree of cooperation with the surgeon, a reciprocal understanding of the potential problems, and adequate preparation on both sides to meet the anticipated challenges that may arise. ${ }^{1,2}$ Thorough appreciation by the anesthesiologist of the complexity of the upper airway anatomy, the pathologic process involved, and all steps of the surgical procedure is necessary for devising a rational anesthetic plan and maintaining a good working relationship with the surgeon. ${ }^{3}$ The expert ability to safely share the patient's airway with the surgeon, in conjunction with an intimate knowledge of possible immediate intraoperative and early postoperative complications of laryngeal surgery, greatly contributes to safe patient management in the perioperative period. Microlaryngeal surgery encompasses a wide range of laryngeal procedures that can be organized in two broad categories: phonomicrosurgery (i.e., benign and malignant vocal cord lesions, laser laryngeal surgery, and vocal cord augmentation) and laryngeal framework surgery (i.e., vocal cord paralysis and motion disorders, scarring, stenosis of the glottic, subglottic, and tracheal areas, and laryngeal trauma). Patients presenting for microlaryngeal surgery may have a variety of comorbidities contributing to their voice symptoms and affecting anesthetic management. Changes in voice quality can be exag- 
gerated by inadequate airflow production (e.g., chronic obstructive pulmonary disease [COPD]) or vocal fatigue caused by neuromuscular disorders (e.g., myasthenia gravis, muscular dystrophy, Parkinson's disease). ${ }^{4}$ Various rheumatologic and musculoskeletal ailments can alter posture, impairing voice quality, and endocrine disorders, such as hypothyroidism, can cause dysphonia as a result of swelling in the Reinke's space (i.e., superficial lamina propria) of the vocal cords. Many patients presenting for laryngeal surgery have a long history of heavy smoking and drinking. ${ }^{5}$ Many of them are elderly and have cardiovascular disease. Appropriate diagnostic tests are indicated for them as part of the preoperative work-up. The pulmonary status of COPD patients should be optimized to decrease airway reactivity and the possibility of postoperative pulmonary complications.

\section{Material and methods}

We obtain approval from local ethical review board and informed consent from all study participants. A 5-year prospective cohort study of 200 patients who underwent microlaryngeal surgery in the Department of ENT Surgery; University Hospital "Queen Giovanna"- ISUL; Medical University-Sofia. In all patients we used quamatel $20 \mathrm{mg}$ for premedication. For induction in general anesthesia we used propofol $2.5 \mathrm{mg} \cdot \mathrm{kg}-1$ and succinylcholine 1 $\mathrm{mg} . \mathrm{kg}-1$ as muscle relaxant. Endotracheal intubation was performed by endotracheal tube №6.0 or №6.5 from the anesthesiologist and mechanical ventilation was performed. For maintenance of general anesthesia we used sevoflurane inspiratory concentration of 2.5 vol. $\%$ and fentanyl $4-5 \mu \mathrm{g}$. $\mathrm{kg}-1$. for pain relief.
All patients were monitored and recorded for: Systolic blood pressure (SBP), Diastolic blood pressure (DBP); heart rate (HR); continuous electrocardiography (ECG). The above parameters were recorded and analyzed at predetermined time intervals: 5-th minute before intubation, every 5 minutes after intubation and 5-th minute after extubation. Descriptive statistical analysis of the results was performed.

European Society of Hypertension (ESH) and the European Society of Cardiology (ESC) classification for arterial hypertension ${ }^{17}$ (fig. 1):

\section{Results}

The mean age of the patients is 59.03 years. According to anesthesia risk assessment $6 \%$ of the patients are with ASA 1 class, $24 \%$ of them are with ASA 2 class, 68\% are with ASA 3 class and $2 \%$ are with ASA 4 class.

We found that $86 \%$ of the patients were men and $14 \%$ were women (fig. 2 )

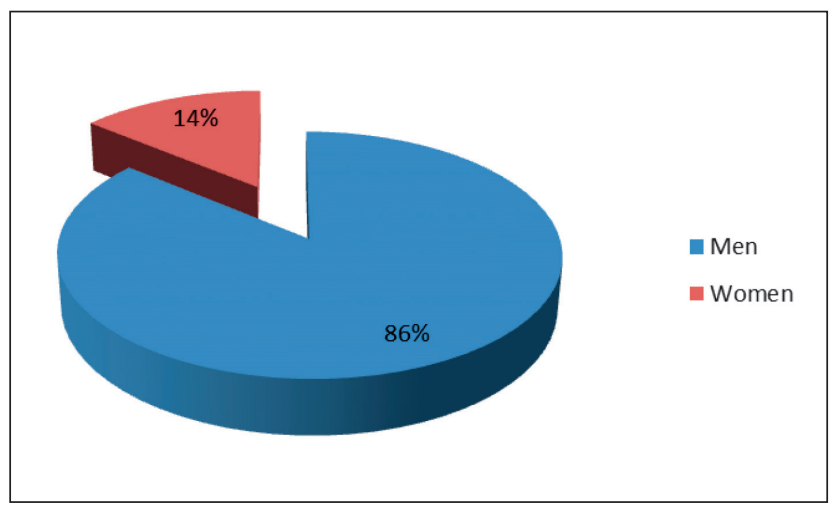

Figure 2. Distribution according to gender.

\begin{tabular}{|l|c|c|c|}
\hline Category & Systolic blood pressure & & Diastolic blood pressure \\
\hline OPTIMAL & $<120 \mathrm{mmHg}$ & and & $<80 \mathrm{mmHg}$ \\
\hline Normal & $120-129 \mathrm{mmHg}$ & and/or & $80-84 \mathrm{mmHg}$ \\
\hline High normal & $130-139 \mathrm{mmHg}$ & and/or & $85-89 \mathrm{mmHg}$ \\
\hline Arterial hypertension I & $140-159 \mathrm{mmHg}$ & and/or & $90-99 \mathrm{mmHg}$ \\
\hline Arterial hypertension II & $160-179 \mathrm{mmHg}$ & and/or & $100-109 \mathrm{mmHg}$ \\
\hline Arterial hypertension III & $\geq 180 \mathrm{mmHg}$ & and/or & $\geq 110 \mathrm{mmHg}$ \\
\hline Isolated systolic hypertension & $\geq 140 \mathrm{mmHg}$ & and & $<90 \mathrm{mmHg}$ \\
\hline
\end{tabular}

Figure 1. Classification for arterial hypertension. 
Mean systolic blood pressure of the patients during the operation is $147.33 \mathrm{mmHg}$, mean diastolic blood pressure is $93.5 \mathrm{mmHg}$ and mean pulse rate is 57.64 beats per minute (fig. 3 ).

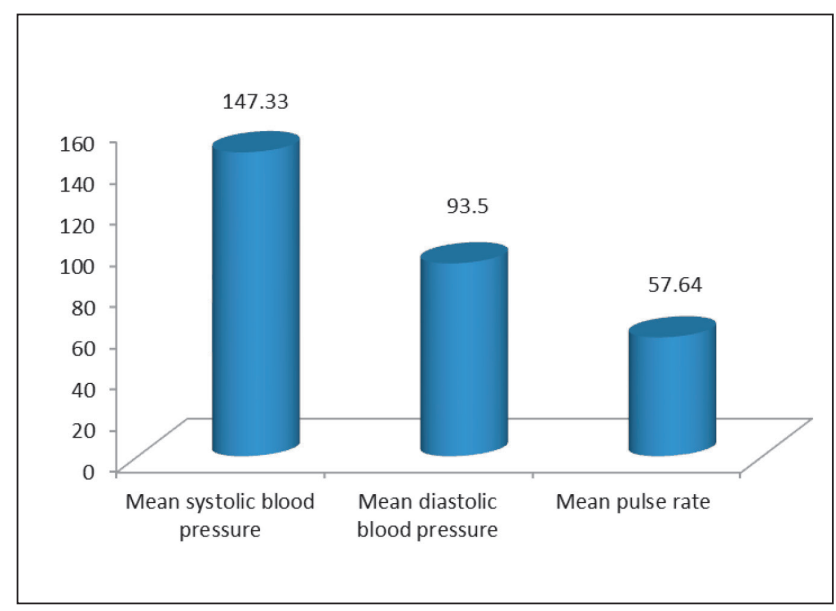

Figure 3. Mean parameters of hemodynamic.

$49 \%$ of the patients have arterial hypertension I grade during the operation, $28 \%$ of them are with isolated arterial hypertension and $23 \%$ are with normal blood pressure (fig.4).

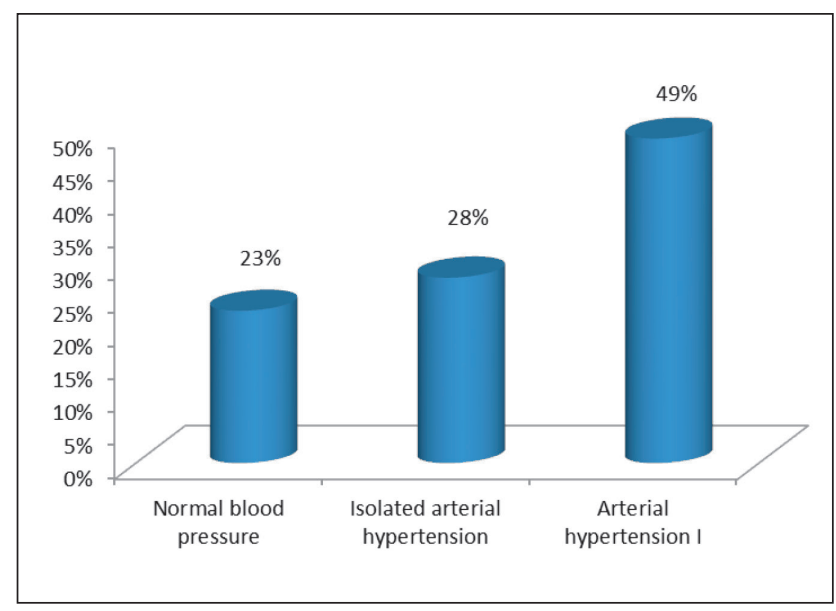

Figure 4. Most of the patient are with hypertensive hemodynamic.

$40 \%$ of the patients had pulse rate between $45-60$ beats per minute during putting on the tube of Kleinsasser, $29 \%$ of them had pulse rate $>60$ beats per minute during putting on the tube of Kleinsasser and $31 \%$ had pulse rate $<45$ beats per minute during putting on the tube of Kleinsasser (fig.5).

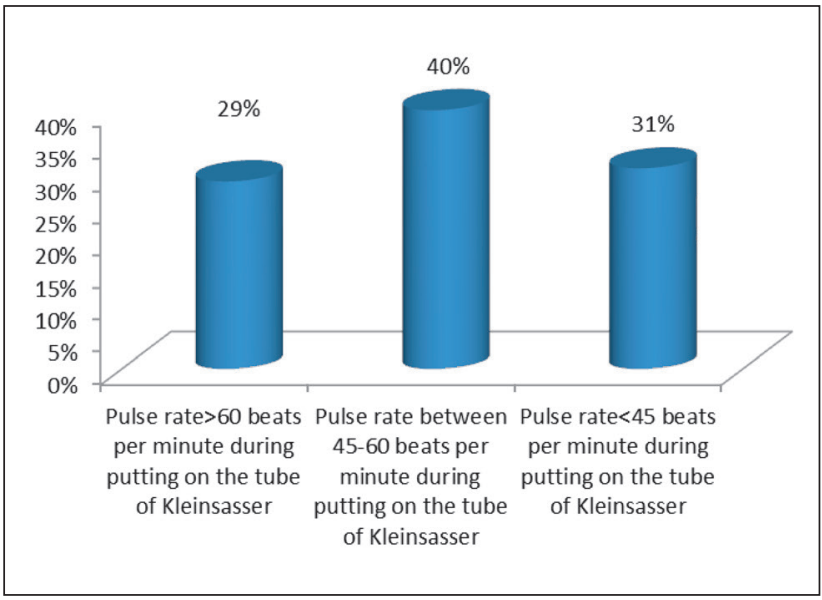

Figure 5. Bradycardia after putting on the tube of Kleinsasser.

\section{Discussion}

The essential requirements for precision microlaryngeal surgery and optimal preservation of function include a clear and still surgical field, absence of patient movement, and allocation of sufficient time to carefully complete the procedure in an unhurried manner. The patient's airway must be protected from blood, debris, and irrigation fluid and ventilation must be adequately controlled. ${ }^{6}$ The anesthesiologist must safely share the patient's airway with the surgeon, and must be prepared to skillfully and confidently switch from one ventilation technique to another during the case if needed or dictated by surgery.

Performance of conventional and operative direct laryngoscopy, supraglottic tissue distention, and laryngeal stimulation elicit intense cardiovascular responses, resulting in tachycardia, arterial and pulmonary hypertension, and arrhythmias. ${ }^{7-9}$ Although these responses are usually short lived, myocardial ischemia and compromise of cerebral circulation may occur in high-risk patients, resulting in adverse outcomes. ${ }^{10-12}$ Anesthetic technique should ensure a stable plane of anesthesia, nonstimulating emergence from anesthesia, a rapid return of consciousness, and protective airway reflexes, and it should facilitate quick discharge of patients, because most of these surgical procedures are done on an outpatient basis.

In our study the mean age of the patients is 59.03 years which means that these are people in active working age. This kind of operation gives them chance to keep their ability to speak and work normally. On the other hand in this age group the risk of accompanying cardiovascular and respiratory 
disease is higher. In this case the risk of hemodynamic complications will be higher. Most of the patients are males $86 \%$. This may be connected with higher incidence of accompanying risk factors like smoking in male group, which is common for Bulgarian population. ${ }^{13-16}$ The anesthesia risk assessment shows that most of the patients are in ASA III class $68 \%$. This means higher risk of accompanying cardiovascular disease and higher risk of hemodynamic complications. $49 \%$ of the patients have arterial hypertension I grade and 28\% of them are with isolated arterial hypertension during operation despite of higher dosage of opioids and propofol that we used. This may be caused by the strong pain stimulus from the tube of Kleinsasser during the operation. $40 \%$ of the patients had pulse rate between $45-60$ beats per minute and $31 \%$ of them had pulse rate $<45$ beats per minute during putting on the tube of Kleinsasser. This is very dangerous reflex reaction of the heart, which we believe is caused by parasympathetic nervous system, because in some of the cases the pulse rate is corrected after administration of atropine. In other cases when the bradycardia is very severe administration of atropine cannot help so the tube of Kleinsasser must be removed, because there is a risk of cardiac arrest. After removing the tube and administration of atropine the pulse rate is normalized.

\section{Conclusion}

Microlaryngeal surgery is specific kind of surgery which is characterized by hypertensive hemodynamic. There is a risk of severe bradycardia after putting on the tube of Kleinsasser which can cause hemodynamic instability and even cardiac arrest if not corrected immediately.

\title{
References
}

1. Webster AC: Anesthesia for operations on the upper airway. Int Anesthesiol Clin 10:61-122, 1972.

2. Agosti L: Anaesthetic technique for microsurgery of the larynx. Anaesthesia 32:362-365, 1977.

3. Welty P: Anesthetic concerns and complications during suspension microlaryngoscopy procedures. CRNA 3:113-118, 1992.

4. Rosen CA, Simpson CB: Operative techniques in laryngology, Berlin, 2008, Springer-Verlag.

5. Rees L, Mason RA: Advanced upper airway obstruction in ENT surgery. Br J Anaesth CEPD Rev 2:134-138, 2002.

6. Pollard BJ: Anaesthesia for laryngeal microsurgery. Anaesthesia 23:534-542, 1968.

7. Shribman AJ, Smith G, Achola KJ: Cardiovascular and catecholamine responses to laryngoscopy with and without tracheal intubation. Br J Anaesth 59:295-299, 1987.

8. Hassan HG, el-Sharkawy TY, Renck H, et al: Hemodynamic and catecholamine responses to laryngoscopy with vs. without endotracheal intubation. Acta Anaesthesiol Scand 35:442-447, 1991.

9. Kaplan JD, Schuster DP: Physiologic consequences of tracheal intubation. Clin Chest Med 12:425-432, 1991.

10. Siddiqui N, Katznelson R, Friedman Z: Heart rate/blood pressure response and airway morbidity following tracheal intubation with direct laryngoscopy, GlideScope and Trachlight: A randomized control trial. Eur J Anaesthesiol 26:740-745, 2009.

11. Thompson JP, Hall AP, Russell J, et al: Effect of remifentanil on the haemodynamic response to orotracheal intubation. Br J Anaesth 80:467-469, 1998.

12. Kahl M, Eberhart LH, Behnke H, et al: Stress response to tracheal intubation in patients undergoing coronary artery surgery: Direct laryngoscopy versus an intubating laryngeal mask airway. J Cardiothorac Vasc Anesth 18:275-280, 2004.

13. Маринов Ц., М. Белитова, Т. Попов, Ю. Рангачев, Д. Попова. Рискови фактори за възникване на периоперативни усложнения при пациенти подложени на ларингектомии. ОтоРиноЛарингология международен бюлетин, XIV, 2018;3:14-18.

14. Маринов Ц., М. Белитова, Т. Попов, Д. Конов, М. Цекова-Чернополска, М. Милков. Разпространение и значимост на ларингеалния карцином. ОтоРиноЛарингология международен бюлетин, XIV, 2018;1:23-27.

15. Маринов Ц., М. Белитова, Т. Попов. Характеристика на контингента пациенти с ларингеален карцином в Българската популация. Анестезиология и интензивно лечение, XLV, 2016;3:11-14.

16. Маринов Ц., М. Белитова, Т. Попов. Соматични проблеми при пациенти с карцином на ларинкса и ларингектомия. Анестезиология и интензивно лечение, XLIV, 2015;4:30-33.

17. Mancia, Giuseppe, et al. „2013 Practice guidelines for the management of arterial hypertension of the European Society of Hypertension (ESH) and the European Society of Cardiology (ESC): ESH/ESC Task Force for the Management of Arterial Hypertension.“ Journal of hypertension 31.10 (2013): 1925-1938.

\author{
Correspondence to: \\ Tsvetomir Marinov, MD, PhD \\ Department of Anesthesiology and Intensive Care \\ University Hospital “Queen Giovanna”- ISUL \\ Byalo More Str 8 \\ Medical University-Sofia \\ E-mail: ts.marinov@abv.bg
}

